\title{
Washington Meeting Examines the State of the Discipline and More
}

A PSA's Annual Meeting returns to Washington, DC, this summer after a three-year hiatus. The Program Committee, led by Ira Katznelson and Helen Milner of Columbia University, has put together a challenging program of over 700 panels, roundtables, and poster sessions. In addition, a number of special plenary sessions featuring public figures and addressing such diverse topics as civic education and the state of the political science discipline deserve your attention.

In their capacities as editors of the Association's third edition of the State of the Discipline, Program Co-Chairs Katznelson and Milner have organized 13 panels devoted to the theme "Political Science as Discipline?" Among the topics to be addressed in the theme panels are "Choice, Power, and Security," "American Politics and Institutions," "Justice and the State in Political Theory," and "The Character of Comparative Politics."

Harvard Law School professor Lani Guinier will speak at a plenary on Friday evening sponsored by the Organized Section on Foundations of Political Theory. A scholar of voting rights, race, and gender, Guinier joined the Harvard Law faculty in 1998 to become its first tenured African-American woman. In 1993, President Clinton nominated her to be the first African-American woman to head the Civil Rights Division of the Department of Justice. The nomination was soon mired in controversy, and Guinier withdrew her name from consideration. Prior to this, Guinier was a civil rights attorney with the NAACP Legal Defense and Education Fund and the U.S. Department of Justice.

The Clinton presidency will be the topic of another plenary scheduled for Friday evening. Participants have not all been confirmed by the program co-chairs, but be sure to visit APSANet throughout the summer for more details.

Four plenaries are scheduled for Saturday evening.

- Daniel Patrick Moynihan, the senior senator from New York and long-time member, will be the featured speaker during a special public policy plenary session. The ranking minority member of the Senate Committee on Finance, Moynihan will speak on "Government Work: Forty Years of National Politics." He currently serves on the Senate Committee on Environment and Public Works and the Senate Committee on Rules and Administration. Moynihan has previously served as professor of government at Harvard University, assistant professor of government at Syracuse University, and a fellow at the Center for Advanced Studies at Wesleyan University. He earned his M.A. and Ph.D. from Tufts University's Fletcher School of Law and Diplomacy.

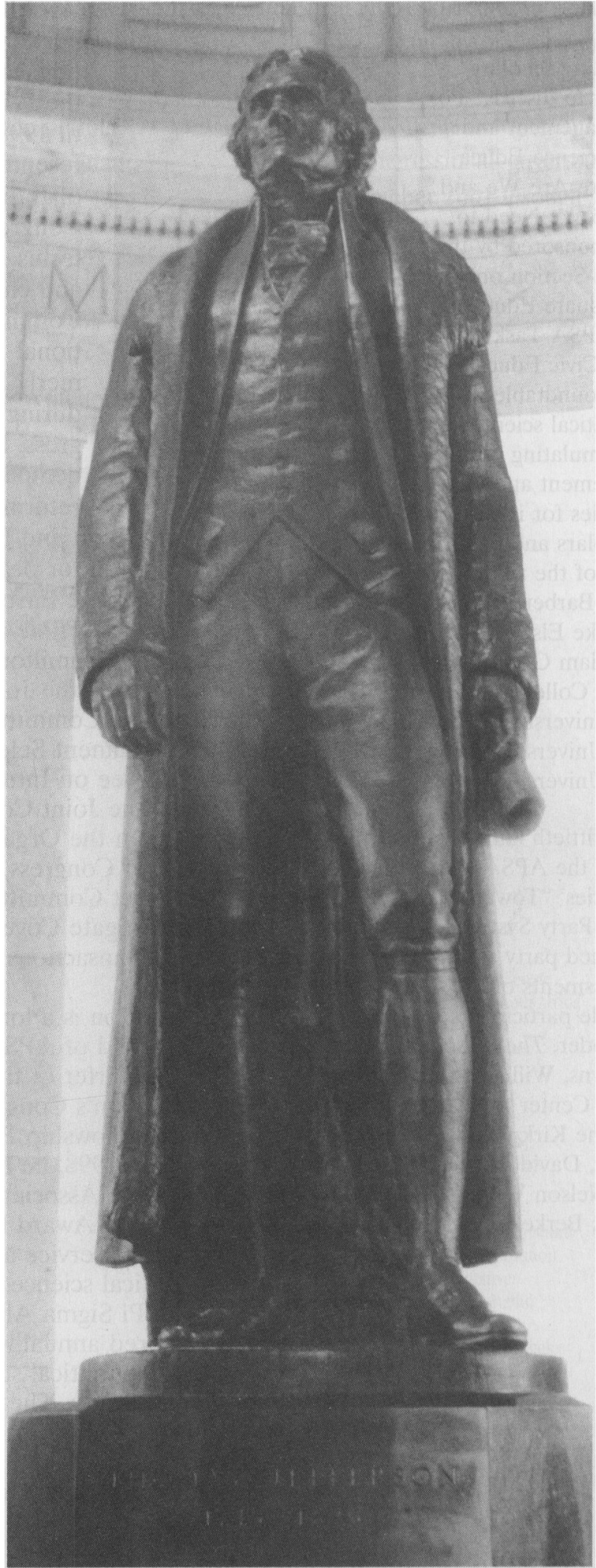

Photo courtesy of Washington Convention and Visitors Assn. 
- The Organized Section on New Political Science and the Women's Caucus in Political Science will co-host a plenary on "Politics in the Twenty-First Century: Does Anyone Care?" The session will feature Barbara Ehrenreich, an awardwinning political essayist, columnist, and social critic. Ehrenreich is a Guggenheim fellow and her latest book is Blood Rites: Origins and History of the Passions of War.

- Six leading scholars will gather to discuss "Political Engagement and Political Science Education: Where Are We and Where Do We Need to Be?" Cosponsored by the Organized Section on Undergraduate Education and the APSA Task Force on Civic Education, the roundtable will assess political scientists' role in stimulating political engagement and identify activities for interested scholars and departments. Members of the roundtable will include Benjamin Barber, Rutgers University, Jean Bethke Elshtain, University of Chicago, William Galston, University of Maryland, College Park, Elinor Ostrom, Indiana University, Robert Putnam, Harvard University, and Theda Skocpol, Harvard University.

- On the fiftieth anniversary of the publication of the APSA Committee on Political Parties' "Toward a More Responsible Two-Party System," a group of distinguished party scholars will offer their assessments of the report's legacy. Roundtable participants will include: David Broder, The Washington Post, James Burns, Williams College, Ralph Goldman, Center for Party Development, Jeane Kirkpatrick, Georgetown University, David Mayhew, Yale University, and Nelson W. Polsby, University of California, Berkeley.

\section{Lee Hamilton to Deliver Pi Sigma Alpha Lecture}

Lee $\mathrm{H}$. Hamilton, director of the Woodrow Wilson International Center for Scholars will deliver the Pi Sigma Alpha Lecture on Thursday, August 31, at 5:30 p.m. at APSA's Annual Meeting in Washington, DC.

Hamilton is the first nonacademic to head the Wilson Center. Until 1998, Hamilton represented the 9th District of Indiana in the U.S. Congress for seventeen terms. As a member and chair of the House Committee on International Relations (formerly Foreign Affairs) during the 103rd Congress, he promoted democratic and market reform in the former

Soviet Union and Eastern Europe and worked for peace and stability in the Middle East.

During his time in Congress, Hamilton also chaired the Joint Economic Committee, the Permanent Select Committee on Intelligence, the Joint Committee on the Organization of Congress, and the Select Committee to Investigate Covert Arms Transactions with Iran.

Hamilton is a longtime friend of APSA and supporter of the Association's Congressional Fellowship Program. In 1998, he received the Association's Hubert H. Humphrey Award for his outstanding public service and commitment to political science.

The Pi Sigma Alpha lecture is sponsored annually by Pi Sigma Alpha, the political science national honor society. The lecturer is typically from the world of politics and past lecturers have included such notables as U.S. Rep. John Lewis, and then-Secretary of Defense Richard Cheney.

\section{Important Information for Annual Meeting Paper Authors}

APSA will begin accepting submissions for PROceedings (http:// pro.harvard.edu), the Association's online collection of Annual Meeting papers, on July 1. Authors can submit papers through September 3, when the meeting ends.

An invitation to participate and submission instructions were mailed to paper authors in May. Those who have not received this information should consult the submission web site (http://papers.tcnj.edu), which opens July 1 , or contact the PROceedings project team at proceedings@apsanet.org.

All authors are expected to submit their meeting papers to PROceedings. To ensure that doing so is as hassle free as possible, APSA will send every paper author for whom it has a valid email address an "Express Pass." Authors can submit papers by using their pass, following the instructions on the submission web site, or emailing the text to the address above.

Developed and maintained by William J. Ball of The College of New Jersey, the PROceedings web site debuted during the 1997 APSA meeting and currently features more than 1,100 papers delivered at the 1999 meeting. Visitors can search the collection using authors' names, paper titles, keywords, or an abridged index from the Annual Meeting Program, and can download their selections using the Adobe Acrobat Reader. Papers from the 2000 meeting will first be available on August 16.

PROceedings is a joint project of APSA, The College of New Jersey, and the Harvard University Library. The Andrew W. Mellon Foundation provided funding for the project. Its success will depend on high levels of participation from authors and constructive feedback from collection users. Questions or comments about the project should be directed to proceedings@apsanet.org. 